\title{
Leadership of Schools in Improving Teacher Discipline and Motivation
}

\author{
Feriyanti* \\ Magister of Educational Administration \\ Syiah Kuala University \\ Banda Aceh, Indonesia \\ *feriyanti341@gmail.com
}

\author{
Murniati A.R., Nasir Usman \\ School of Educational \\ Syiah Kuala University \\ Banda Aceh, Indonesia \\ murniati@unsyiah.ac.id,nasir@unsyiah.ac.id
}

\begin{abstract}
The leadership of the principal as the top manager has a strategic role in increasing teacher discipline and motivation. The purpose of this study was to determine the policies, programs, strategies, supporting and inhibiting factors of the principal's program in improving the discipline and motivation of teachers at 16 Public Senior High Schools and 12 Public Senior High Schools in Banda Aceh City. This study uses a descriptive qualitative approach. The technique of collecting data is interview, observation, and documentation study. The research subjects were school principals, vice principals and teachers. The results showed (1) the principal's policies in increasing discipline and motivation in making school rules and order involved school elements including the vice principal and teachers. (2) preparation of school principal programs in improving teacher professionalism, including compiling annual programs, semester programs, learning planning steps; (3) strategies to improve teacher discipline and motivation by dividing tasks, holding trainings and attending MGMP and providing understanding (4) supporting factors in increasing discipline and motivation of teachers, most of whom already have teacher certificates, while the inhibiting factor is teachers who live far away. from schools, there are still teachers who are less active, and the results of the training have not been able to be disseminated to their friends, the level of awareness differs between teachers.
\end{abstract}

Keywords-inhibiting and supporting factors, policies, programs, principal strategy

\section{INTRODUCTION}

Education is a process to improve the quality of human resources, the success of the world of education as an indicator of the achievement of national development goals in the field of education, namely the intellectual life of the nation. As one of the formal educational institutions, schools have an important role in realizing the goals of national education. School is an educational institution, there are several components that are interrelated. The components include principals, teachers, students, administrative staff, the environment and the community.

The achievement of educational or school goals is greatly influenced by the quality of the school, the quality of the school is influenced by the quality of the teachers in the school.
The quality of teachers is strongly influenced by the level of education, level of discipline and motivation. With the existence of discipline and good motivation from teachers, it can be a driving force of learning activities - teaching in schools and become role models for other teachers, students or other school elements. The level of discipline and motivation of teachers is strongly influenced by the rules and programs adopted by the principal. The principal has an important role in enforcing teacher discipline and influences the level of motivation of the teachers he leads. Leadership is an intimidating subject and an even more challenging role [1].

The school principal has a very important role in mobilizing and harmonizing all educational resources available in schools and using them as needed. This means that the leadership of the principal is one of the factors that can realize the vision, mission, goals and objectives of the school through planned and gradual programs. Principals are required to have adequate managerial and leadership skills in order to be able to take initiatives and initiatives to improve the quality of education in schools. argues that: management and leadership of school principals need to be emphasized more in coordination, communication and supervision, because weaknesses and barriers to education often result from a lack of coordination, communication, and supervision, causing different perceptions among implementing components in the field (head of offices, supervisors, school principals, and teachers) Over the past few years there has been no conflict between these elements, the creation of harmony and synergy in 16 Public Senior High Schools and 12 Public Senior High Schools in Banda Aceh City, in the end it has led to various achievements both in the academic and non-academic fields. The key to creating harmony and synergy lies in the leadership of the principal, where the leadership of the principal provides motivation, is fair, provides good role models, provides guidance on increasing the competence of teachers, applies regulations in accordance with applicable regulations and always maintains good relationships with the surrounding community. Leaders of future schools must become both reflective practitioners and life-long learners that understand the importance of the intellectual aspects of leadership, and 
authentic in their leadership practices in the sense that many scholars have advocated for some time [2].

As for the problem formulation in this study is "How the Principal's Leadership in Improving the Discipline and Motivation of Teachers in 16 Public Senior High Schools and 12 Public Senior High Schools in Banda Aceh City.

\section{THEORETICAL FOUNDATION}

\section{A. Definition of Educational Leadership}

Leadership is a person who has the authority to give tasks, has the ability to influence others through good relationship patterns to achieve predetermined goals [3]. That educational leadership is an ability in the process of influencing, coordinating other people who are related to education and the implementation of education and teaching, so that the activities carried out can take place more efficiently and effectively in achieving educational and teaching goals. The principal as a leader in moving the wheels of the school organization determines the success of achieving organizational goals. The principal is a teacher (functional position) who is appointed to occupy a structural position (principal) in the school [4]. Principals who have brought about many changes to schools, including principals who are effective. The leadership style of the principal is a high hope for improving the quality of education, the success of education has a direct influence on student learning outcomes. The principal has the role and function of a supervisor to teachers to develop competence. In increasing teacher competence, the principal is not only a manager, managing learning activities at school, but must be a teaching leader who is in charge of overseeing the teaching and learning activities in the school he leads [4]. The principal is a functional teacher who is given the task of leading a school where a teaching and learning process is held or a place where interactions occur between teachers who give lessons and students who receive lessons [5]. Meanwhile, Principal leadership provides work motivation to increase teacher work productivity and student learning outcomes [5]. The leadership of the principal must be accounted for because the responsibility of the principal is in terms of the extent to which the principal encourages his subordinates to work in accordance with the policies and programs that have been outlined so that discipline, productivity, and high teacher performance and student learning outcomes increase.

\section{B. Leadership Type Principal}

Leadership style is a style used by a leader to manage power and can influence his subordinates [6]. Leadership is the ability to mobilize and direct people to the goals the leader wants to want [6]. This means that at certain stages, leadership can be used as a means of mobilizing and as a function of management. As a principal, of course, in carrying out daily tasks, it cannot be separated from the type of leadership used. The headmaster type of leadership is the method the principal uses in influencing teachers and other employees. The manifestation and each type of leadership cannot be separated from the influence of changing conditions. This means that the application of each type of leadership depends on the leadership's ability to analyze and take advantage of the changing conditions.

\section{The Types of Leadership}

The types of leadership are as follows:

- Autocratic or Authoritarian Leader, this type of leadership is the oldest type known to humans, placing power in the hands of one person or a small group of people among whom there is still someone who is most powerful. Based on the above opinion, it can be concluded that the essence of autocratic leadership is the power that is in the hands of the leader and does not allow his subordinates to interfere, so that subordinates are only used as executors of decisions. Leaders with this type usually tend to be selfish because they want to be the sole ruler and do not consider and ignore their subordinates. All decisions are made independently and require subordinates to carry out.

- Permissive or free leader (Laissez Faire), states that the meaning of the word permissive is all-permissive, affirmative, doesn't want to bother, and acts in its true meaning. Leaders do not have a strong founder, their attitude is permissible. The nature of leadership in this type seems invisible, because the leader gives full freedom to all members in carrying out their duties. The leader has the belief that by giving the widest possible freedom to his subordinates, all his efforts will quickly succeed. In this type of the leader is a symbol, the leader gives full freedom to the person who is led to make decisions and carry out activities according to the will and interests of each group member. Leadership is carried out without doing anything, because it has been submitted to the people being led. However, if there is an error the dreamer always leaves his hands because he does not participate in determining it. In line with this opinion, Daryanto argues that leadership is carried out by giving full freedom to the person being led. The leader only functions himself as an advisor, which is done by providing the opportunity to ask questions for group members who need it. Based on the explanation above, the laissez faire leadership type is a type of leadership that positions the leader only as a symbol. It can also be said that this type is the opposite of the authoritarian type, because in this type subordinates are given the freedom to make decisions and carry out activities according to their wishes. It is different from the authoritarian type where subordinates are only considered executors who cannot interfere in all matters.

- Democratic leaders say that the core of democracy is openness and the desire to position the work of, by, and to be together. The foundation of democratic leadership is the assumption that with dynamic interactions the 
organizational goals will be achieved. In this type of leadership, a leader always includes all group members in making decisions. Some of the leader's power is given to subordinates so that subordinates feel responsible for completing existing tasks. Meanwhile, it is argued that in this type humans are seen as the main and most important factor in any group or organization. In this type of leadership, there is always an effort to take advantage of everyone who is led by providing opportunities for them to participate in every activity. Leaders with democratic types are respected and respected because they are able to develop, maintain and maintain dignity, on the basis of effective human relations.

\section{Principal Policy}

The policy is a series of actions that have a goal that is followed by a person or group of actors related to a particular problem. Education policy is a public policy that specifically regulates regulations relating to the absorption of sources, allocation and distribution of sources, as well as regulating behavior in education, based on the above opinion, it can be concluded that education policy is the whole process and is rare strategic education. to realize educational goals within a certain period of time [7].

Several criteria that must be considered in the formulation of education policies include [7]:

- An educational policy that is to be realized must have clear objectives as desired.

- The desired objectives must be planned.

- There must be a program, namely the efforts and means of the authorities to achieve goals.

- Decisions are all actions to set goals, make plans, implement and evaluate.

- Impacts are the consequences of a program to be implemented and whether intentional or unintentional, both primary and secondary.

Based on several opinions, it can be concluded that education policy is the result of decisions taken by considering the relationship between education and the social component. There are three policy processes, namely:

- Policy formulation, policy formulation contains several important contents which serve as guidelines for the appropriate planned actions. The contents of the policy consist of: a) the interests that are affected by the policy, b) the types of benefits that will be generated, c) the desired degree of change, d) the position of policy makers, e) who is the executor of the program, e) the resources deployed.

- Policy implementation, in principle, is a way that is implemented so that a policy can achieve its objectives. Evaluation of a policy, a policy should not be left alone after being implemented. Once the implementation of the policy takes place then it needs to be checked, on the other hand evaluation is used for.

\section{E. Principal Program}

Ministry of National education quality assurance "The performance assessment of school principals is carried out based on: (a) school / madrasah development efforts undertaken during the tenure of school / madrasah principal; (b) improving the quality of schools / madrasahs based on 8 (eight) national education standards while under the respective leadership; and (c) efforts to develop professionalism as school / madrasah principals". The program is a plan or activity plan that will be carried out by the principal [8].

According to the quote above, the existence of a school principal program will carry out the vision and mission of a school. Running the teaching and learning process in schools effectively and can develop good quality school goals and direction.

\section{F. Work Discipline}

The principal in conducting supervision must apply five principles [4], namely (1) consultative, collegial and not hierarchical relationships, (2) implemented democratically, (3) teacher-centered, (4) based on need, (5) professional assistance. Meanwhile, Education supervision is all efforts that are helping teachers or serving teachers so that they can improve, develop and improve their teaching, as well as provide effective and efficient student learning conditions for the growth of their positions to achieve educational goals and improve the quality of education [8].

\section{G. Work Motivation}

According to George the elements of work motivation are divided into three parts, namely the direction of behavior, level of effort, level of persistence. In working, the direction of behavior refers to the behavior that a person chooses in working from the many choices of behavior that can be carried out, whether appropriate or not. The level of effort and persistence talks about how hard a person tries to work according to the chosen behavior and according to Hasibuan in Kuddy [9], three important things must be considered in providing motivation, namely (1) things that encourage employees are challenging jobs that include feelings of achievement, responsibility, progress, being able to enjoy work and recognition of work results., (2) things that disappoint employees are mainly factors that are appendage to work, job regulations, lighting, rest., 3) employees will be disappointed if the opportunities for achievement are limited.

\section{RESEARCH METHODS}

In this study, the authors used a qualitative approach (Qualitative Research) as a basis for discussing research results. Qualitative method is a research procedure that produces descriptive data in the form of written or spoken 
words from the observed behavior of people [10], while Sugiyono suggests that qualitative research methods are research methods based on to positivism philosophy, it is used to examine the conditions of natural objects [11]. The locations of this research are: in 16 Public Senior High Schools and 12 Public Senior High Schools in Banda Aceh City h. With a research focus, the leadership of school principals in improving discipline and work motivation of teachers in SMA Negeri 16 and SMA Negeri 12 Kota Banda Aceh. The research subjects were data sources related to research and data sources used were all parties related to 16 Public Senior High Schools and 12 Public Senior High Schools in Banda Aceh City In this assessment, the research instrument used observation/ observation, interview guidelines, and documentation study. In qualitative research, data analysis is carried out during data collection and after completing data collection within a certain period. Analyzing the data and information obtained from the beginning of the study to the end of the study by referring to the theoretical basis related to the problem studied, which is related to the management of school principals in the application of Islamic school culture. reduce data), summarize the important things and draw conclusions (data verification) from the research results obtained in the field.

\section{RESULTS AND DISCUSSION}

\section{A. Principal Policy in Improving Discipline and Motivation of Teachers of 16 Public Senior High Schools and 12 Public Senior High Schools in Banda Aceh City}

Based on the results of research on policies, programs and strategies of school principals in improving discipline and motivation of teachers at 16 Public Senior High Schools and 12 Public Senior High Schools in Banda Aceh City, data collection was conducted through interviews, observation and documentation with principals, deputy principals, and teachers. -teacher. The two principals have the same leadership in increasing the discipline and motivation of teachers. The two principals in the formulation of policies to increase teacher discipline and motivation, involve teachers to actively provide ideas, views and ideas on policies to increase discipline and teacher motivation. By involving teachers in the formulation of policies to increase discipline and motivation of teachers, it is hoped that the best policies can be produced and accepted by all school elements. The principal holds a meeting with all teachers once a month, with the aim of finding ideas, views, ideas on problems that arise and to find the best solution, forming commitment and awareness of the teachers. The policy to increase teacher discipline and motivation that has been decided is then socialized to all elements of the school including teachers, so that all teachers know, understand and realize, support policies to increase teacher discipline and motivation. This is in accordance with Maduratna, the principal in taking the lead in implementing a democratic leadership style, which involves all school elements in policy formulation [12] and the principal functions as the leader of an educational organization [4].
The school principal organizes school elements in the formulation of policies for increasing discipline and motivation of teachers. In implementing the policy of increasing discipline and teacher motivation, the principal involved the vice principal of the school. The school principal delegates to the vice principal in the implementation of improving the discipline and motivation of teachers. The implementation of coaching for teachers is always carried out with a familial approach and if necessary, the principal takes firm action against problem teachers, if necessary, the principal takes decisive action in the form of punishment for teachers who are still having problems with discipline and motivation. In accordance with Maduratna, the principal in leading is implementing a democratic leadership style [12].

The principal has a big responsibility in the success of the teaching and learning process in schools. Learning activities depend on the role of the teachers, one of the factors that influence the success of learning is the level of discipline and motivation of the teachers. Principals are aware of the varying degrees of discipline and motivation of teachers. The level of discipline and motivation of teachers affects the quality of teaching performance of teachers in the classroom, so the principal's function is in accordance with Purwanti, that the principal has a leadership task, the principal is expected to be able to lead, direct, guide, influence, nurture teachers -teacher [4]. Where the principal has the following roles as educator, manager, administrator, supervisor, innovator and motivator, it is expected to direct teachers. Leadership in human resource organizational management must have (a) the presence of a leader and other people who are led or followers, (b) there is an effort or process to influence from leadership to others through various strength, (c) the existence of a final goal to be achieved together with leadership, (d) leadership can arise in an organization or a sign of a particular organization, (e) a leader can be formally appointed or elected by followers, (f) leadership is in a particular situation of both the follower's situation and the external environment [13].

\section{B. School Principal Program in Improving Discipline and Motivation of Teachers of in 16 Public Senior High Schools and 12 Public Senior High Schools in Banda Aceh City}

Based on the results of research on the principal's program in improving discipline and motivation of teachers of in 16 Public Senior High Schools and 12 Public Senior High Schools in Banda Aceh City, the collection of research data was carried out through interviews, observation and documentation with the principal, vice principal, and teachers. The two principals have similarities in leadership in increasing discipline and motivation. The two principals in preparing programs for increasing discipline and motivation for teachers, involve teachers to actively provide ideas, views and ideas about programs to increase discipline and teacher motivation. By involving teachers in the formulation of programs for increasing discipline and teacher motivation, it is hoped that the best policies can be produced and accepted by all school 
elements. The principal holds a meeting with all elements of the school once a month, with the aim of finding ideas, views, ideas on problems that arise and to find the best solution, forming commitment and awareness of the teachers. The principal organizes school elements in the implementation of programs for improving teacher discipline and motivation. Implementation of programs for increasing discipline and teacher motivation, the principal involves the vice principal of the school. The school principal delegates to the vice principal in the implementation of improving the discipline and motivation of teachers. The implementation of the coaching program for teachers is always carried out with a familial approach and if necessary, the principal takes firm action against problematic teachers. If necessary, the principal takes firm action in the form of punishment for teachers who are still having problems with discipline and motivation.

The program to improve discipline and teacher motivation that has been decided is then socialized to all elements of the school including teachers, so that all teachers know, understand and are aware of, support programs to increase teacher discipline and motivation. Teachers' discipline and motivation improvement programs are arranged in a neat and orderly manner according to a clear timeline. This is in accordance with Maduratna, the principal in taking the lead in implementing a democratic leadership style [12].

\section{Principals' Strategies in Improving Discipline and Motivation of Teachers at in 16 Public Senior High Schools and 12 Public Senior High Schools in Banda Aceh City}

Based on the results of research regarding the principal's strategy in improving teacher discipline and motivation, the collection of research data was carried out through interviews, observation and documentation with school principals, vice principals, teachers. Both school principals have similarities in leadership in increasing discipline and motivation teachers. The two principals used strategies to increase discipline and teacher motivation, involving teachers to actively provide ideas, views and ideas about strategies for increasing discipline and teacher motivation. By involving teachers in the formulation of increased discipline and teacher motivation, it is hoped that it can be accepted by all elements of the school. The principal holds a meeting with all elements of the school once a month, with the aim of finding ideas, views, ideas on problems that arise and to find the best solution, forming commitment and awareness of teachers. The strategy to increase teacher discipline and motivation that has been decided is then disseminated to all elements of the school including teachers, so that all teachers know, understand and realize, support the strategy to increase teacher discipline and motivation.

The principal organizes school elements in the implementation of strategies for increasing discipline and teacher motivation in implementing strategies for increasing discipline and teacher motivation, the principal involves the vice principal of the school. The school principal delegates to the deputy principal in the implementation of improving the discipline and motivation of teachers. The implementation of the coaching program for teachers is always carried out with a family approach and if necessary, the principal takes firm action against problem teachers, if necessary the principal take decisive action in the form of punishment for teachers who are still having problems with discipline and motivation.

The level of discipline and motivation of teachers affects the quality of teaching performance of teachers in the classroom, so the principal's function as leaders of educational organizations as follows: educators, managers, administrators, supervisors, innovators and motivators are expected to direct teachers [14].

\section{Barriers and Challenges and Solutions to Overcome} Problems That Arise in in 16 Public Senior High Schools and 12 Public Senior High Schools in Banda Aceh City

From the results of research on principal leadership in improving discipline and teacher motivation in 16 Public Senior High Schools and 12 Public Senior High Schools in Banda Aceh City. The discipline and motivation improvement program face obstacles that hinder the achievement of policies and programs. As for the obstacles that arise, such as not all teachers have the same level of awareness, different levels of experience, different levels of age, different tenure, distance from domicile to school far, different levels of motivation, level of mastery of different technologies and different levels of competence, different levels of education.

The implementation of discipline, teacher motivation is strongly influenced by internal factors of the teacher's level of awareness and understanding of different disciplines. In addition, it is strongly influenced by external factors such as the leadership of the school principal, the school environment and the facilities that support learning activities in schools, government regulations. The two principals took the rare task of conducting either spiritual guidance or increasing competence, giving awards and sanctions. It is hoped that the leadership of the principal can harmonize all elements so that the level of discipline and motivation is maintained. High teacher discipline and motivation will affect the teaching and learning process activities so that the objectives of the teaching and learning process are achieved, namely the implementation of quality teaching and learning activities and the academic achievement of students can be achieved and maximized. The principal is required to have the ability to provide motivation, provide motivation to teachers who have problems with discipline and motivation, the teacher's actions are in accordance with Triana, where the principal is required to provide motivational encouragement to teachers [15].

\section{CONCLUSION}

- Principal policies in increasing discipline and teacher motivation the principal involves all school elements in the formulation, determination and implementation, evaluation of discipline improvement policies, and motivation of teachers. The school principal 
disseminates the discipline and motivation improvement program for all elements of the school, including teachers. With the socialization of increasing discipline and motivation of teachers, it is hoped that teachers will know, understand and carry out the results of meetings or programs to improve discipline and motivation that have been mutually agreed upon.

- The principal's program in improving teacher discipline and motivation. Teachers must attend and return, must make learning tools, conduct an evaluation at the end of the semester, hold teacher competency and capacity training, each period a meeting is held to provide direction and guidance. Deputy principals are involved in the process of drafting, implementing and evaluating the program to increase the discipline and motivation of teachers. In the meeting discussed the discipline of students and teachers, forming a curriculum development team, forming a continuous performance appraisal team and teacher performance appraisal, forming a supervision team.

- The principal's strategy in increasing teacher discipline and motivation, the principal makes discipline as a strategy for carrying out learning activities in schools, discipline in implementing programs that have been decided can be implemented, teaching and learning activities in schools can be controlled. The teaching and learning process activities in class must be in accordance with a predetermined schedule, in the teaching and learning process activities the teachers must do student-student attendance, providing student learning materials must be in accordance with the learning plan that has been prepared. Providing rewards and punishments, rewards for outstanding teachers, it is hoped that the teacher concerned will be more motivated and for other teachers can emulate or imitate the teacher.

- Barriers and support in increasing the competence of teachers in schools. The principal in increasing the discipline and motivation of teachers, encounters problems with different levels of awareness, problem levels from internal and external factors of teachers, to overcome existing problems, regular recitation is held to increase spirituality, it is hoped that with competency training and spiritual guidance it can increase awareness discipline and motivation of teachers.

\section{REFERENCES}

[1] D.B. Reeves, The daily disciplines of leadership: How to improve student achievement, staff motivation, and personal organization. John Wiley \& Sons, 2003.

[2] P.T. Begley and J.A. Stefkovich, "Introduction: Education, ethics, and the 'cult of efficiency': Implications for values and leadership," J. Educ. Adm., 2004.

[3] A. Wagito, "Hubungan antara Motivasi Kerja Guru dan Kepemimpinan Kepala Sekolah dengan Disiplin Kerja Guru," Manajer Pendidik., vol. 10 , no. 6, 2016.

[4] K. Purwanti, A.R. Murniari, and Y. Yusrizal, "Kepemimpinan Kepala Sekolah Dalam Meningkatkan Kompetensi Guru Pada Smp Negeri 2 Simeulue Timur," J. Ilm. Didakt. Media Ilm. Pendidik. dan Pengajaran, vol. 14 , no. 2,2014

[5] V. Rusmawati, "Peran kepemimpinan kepala sekolah dalam upaya meningkatkan disiplin kerja guru pada SDN 018 Balikpapan,” J. Adm. Negara, vol. 1, no. 2, pp. 1-19, 2013.

[6] M. Rifa'i, "Pengaruh Kepemimpinan Kepala Sekolah terhadap Disiplin Kerja Guru di SD Negeri 060794 Kecamatan Medan Area,” Manaj. Pendidik. dan Keislam., pp. 42-50, 2018

[7] H. Fajri and A.R. Murniati, "Strategi Kepala Sekolah Dalam Meningkatkan Disiplin Dan Motivasi Kerja Guru SD Negeri 36 Laksana Banda Aceh," J. Adm. Pendidik. Progr. Pascasarj. Unsyiah, vol. 2, no. 2, 2014

[8] A.D. Nopembri, "Fungsi Kepala Sekolah dalam Meningkatkan Kinerja Guru," Manajer Pendidik., vol. 9, no. 3, 2015.

[9] A. Kuddy, "Pengaruh Kepemimpinan, Motivasi, Dan Disiplin Kerja Terhadap Kinerja Pegawai Pada Dinas Pertanian Dan Ketahanan Pangan Provinsi Papua,” Jumabis J. Manaj. dan Bisnis, vol. 1, no. 2, 2017.

[10] L.J. Moleong, "Metodologi Penelitian Kualitatif. Bandung: PT Remaja Rosdakarya..(2009),” Metodol. Penelit. kualitatif (edisi revisi), 2004.

[11] S. Sugiyono, Metode Penelitian Pendidikan: Pendekatan kuantitatif, Kualitatif, dan R\&D. Bandung: Alfabeta, 2015.

[12] M. Maduratna, "Peranan kepemimpinan kepala sekolah dalam meningkatkan efektivitas kerja guru dan pegawai di sekolah dasar negeri 015 Samarinda," J. Adm. Negara, vol. 1, no. 1, pp. 70-84, 2013.

[13] E. Mulyasa, Guru dalam implementasi kurikulum 2013. Bandung: Remaja Rosdakarya, 2014

[14] H. De Keizer and D. Pringgabayu, "Pengaruh Kepemimpinan Kepala Sekolah, Motivasi, dan Budaya Sekolah, Terhadap Kinerja Guru Di SMK ICB Cinta Niaga Kota Bandung," JMBI UNSRAT (Jurnal Ilmiah Manajemen Bisnis dan Inovasi Universitas Sam Ratulangi), vol. 4, pp. 14-24, 2018.

[15] K. Triana, Implementasi Kepemimpinan Transformasional dalam Konteks Manajemen Berbasis Sekolah, studi kasus pada SD InpresHartaco Indah Makassar (Doctoral dissertation). Makassar: Universitas Negeri Makassar, 2015) 